\title{
BIOFENOLOGIA DO COENTRO ${ }^{1}$
}

\author{
José Higino Ribeiro dos Santos ${ }^{2}$ \\ José Maria Arcanjo Alves ${ }^{3}$
}

Recebido em 16.09.91. Aceito em 04.06.92

RESUMO: Estudou-se a biofenologia do coentro, Coriandrum sativum L., com a finalidade de obter-se informaçōes dos aspectos relativos à fase vegetativa e reprodutiva da cultura, como também o comportamento desta olerícola em relaçāo às diferentes épocas de plantio. Concluiu-se que, para as condiçōes do Estado do Ceará, onde as temperaturas são mais baixas próximo ao meio do ano e altas no final e início do ano, o fator que mais influencia a biofenologia do coentro, nesta regiāo, é a temperatura.

Palavra-chave: Coriandrum sativum, fase vegetativa, fase reprodutiva.

ABSTRACT - Phenology of the reprodutive and vegetative growth of coriander,Coriandrum sativum L., was studied as well as the behaviour of that vegetable in relation to different times of sowing. It was concluded, for the conditions of Ceará State, Brazil, which presents lower temperature values near the middle of the year and high her temperature values in the final and beginning the year, that the factor temperature is the one that most influences phenology of coriander.

Key words: Coriandrum sativum, reprodutive and vegetative growth.

\section{Introdução}

O Coentro, Coriandrum sativum L., é uma olerácea anual, herbácea, pertencente à família das umbelíferas, com altura variando entre 80 a 100 centímetros, bastante cultivada no Nordeste brasileiro devido ser um excelente condimento com

1 - Trabalho apresentado no XLI Congresso Nacional de Botânica, Fortaleza - CE.

2 - Departamento de Fitotecnia do Centro de Ciências Agrárias da Universidade Federal do Ceará.

3 - Aluno do Curso de Pós-Graduação em Agronomia - Fitotecnia do CCA-UFC, Fortaleza, Ceará, Brasil. 
sabor e aroma característicos, constituindo-se numa boa fonte de cálcio, ferro, vitamina $\mathrm{C}$ e pró-vitamina $\mathrm{A}$, além de apresentar propriedades medicinais, sendo enquadrada entre as espécies carminativas que obstaculizam a formação de gases intestinais.

O estudo da biofenologia do coentro, faz-se necessário em virtude de sua alta utilização e cultivo nos Estados Nordestinos, principalmente no Ceará. Bezerra et al. (1990), realizaram um diagnóstico do setor hortícola de Fortaleza, em amostragem realizada no primeiro trimestre de 1990 , entre os horticultores deste município e verificaram que $98 \%$ das hortas do cinturão-verde de Fortaleza cultivavam o coentro, o qual ocupava $50 \%$ da área hortícola explorada.

\section{Material e Métodos}

Com o objetivo de estudar a biofenologia do coentro, tendo em vista obter-se informações dos aspectos relativos à fase vegetativa e reprodutiva da cultura, inclusive o comportamento desta olerácea em relação às diferentes épocas de plantio, fez-se, quinzenalmente, a partir de 02.01 .88 , o plantio de cinco repetições, sobre as quais observou-se a quantidade de dias requeridos para a mudança do sistema de folhas e o início da antese, tomando-se como referencial o início da germinação. Trabalhou-se com sementes de coentro oriundas dos mercados de Fortaleza, semeadas em condições de campo no Campus do Pici do Centro de Ciências Agrárias da Universidade Federal do Ceará.

Deste material de coentro comercializado em Fortaleza, fez-se um esquema da planta mostrando os tipos de folhas e um outro esquema indicando os tipos de ramos e umbelas da planta de coentro adulta. Para a fixação e conservação das folhas, usou-se lâminas de vidro sobrepostas, ficando a folha de coentro entre as duas lâminas. O desenho estrutural da planta adulta, deu-se através de observações visuais, na época do amadurecimento dos frutos.

\section{Resultados e Conclusões}

Os resultados obtidos evidenciam que as plantas germinadas nos meses de junho e julho requerem, aproximadamente, 40 e 50 dias para a mudança do sitema de folhas e iniciar a antese, respectivamente, e, a medida que a data de germinação afasta-se do meio do ano, quer para o início ou final do ano, mais dias são requeridos para a ocorrência dos eventos estudados, chegando a diferença a ser superior a 20 dias, nos três primeiros meses do ano, Figura 1 .

Como as temperaturas no Estado do Ceará são mais baixas próximo ao meio do ano e altas no inícı e final do ano, acredita-se que o fator de maior influência na biologia do coentro seja a temperatura, haja vista ser a diferença de fotoperíodo praticamente desprezível quando comparada com a temperatura neste Estado.

A biologia da fase reprodutiva do coentro foi estudada por Santos et al. (1988), tendo em vista o controle da vespinha do fruto Systole coriandri (Hym., 


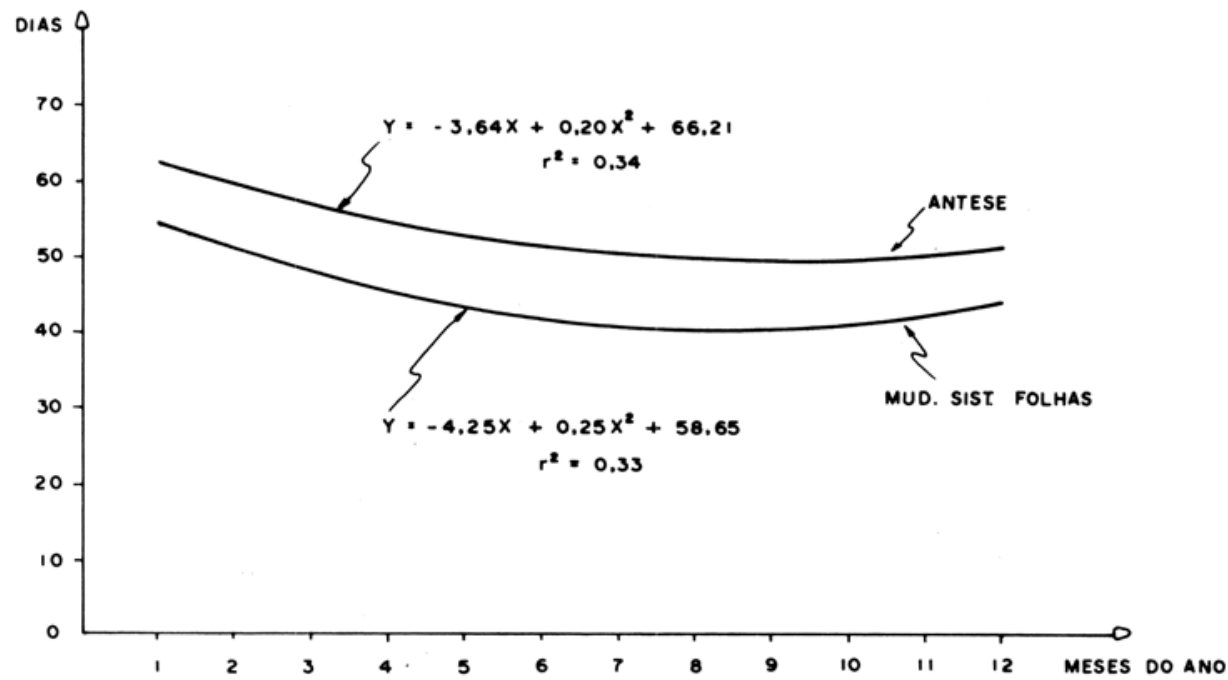

Figura 1 - Quantidade de dias decorridos entre a germinação da planta de coentro, o início da mudança do sistema de folhas e a antese da primeira umbela.

Eurytomidae). Estes autores determinaram que a primeira umbela, ou umbela principal, tem sua inserção no décimo-quinto nó, em média, contando-se-o da base para o ápice da planta, requerendo 52,4 dias para a antese desta umbela. Os picos das curvas temporais de umbelas em antese e umbelas em iníco de amadurecimento são de 57 e 75 dias, respectivamente, tendo como referencial a data da germinação. Os autores mencionados trabalharam com plantios efetuados próximos ao meio do ano, obtendo os resultados justificados em trabalhos posteriores, como mostra a Figura 1.

Examinando-se a Figura 2, observa-se que a planta de coentro apresenta folhas compostas, profundamente partidas e com disposição alternada. As folhas inferiores são do tipo pinatífidas e as superiores, a medida que surgem, evoluem de bi à pentapinatífidas, mostrando uma grande redução na área foliar. Em um determinado momento, na mudança do sistema de folhas, quando a planta mostra os primeiros nós visíveis, as folhas tornam-se imprestáveis ao consumo, por tornarem-se amargas.

Na Figura 3 temos a disposição das inflorecências, do tipo umbela composta, e dos ramos da planta de coentro. A primeira umbela, denominada umbela principal, é a primeira a surgir e é originada da haste principal da planta, inserindo-se, tal como mostra a Figura 3, no décimo nó.

Dos ramos primários e secundários surgem as umbelas primárias e secundárias, respectivamente, responsáveis pela maior quantidade de frutos viáveis na cultura. Estas primeiras classes de umbelas, de acordo com o que foi constatado por Santos et al. (1988), portam mais de 15 frutos por umbela e levam entre 18 e 20 


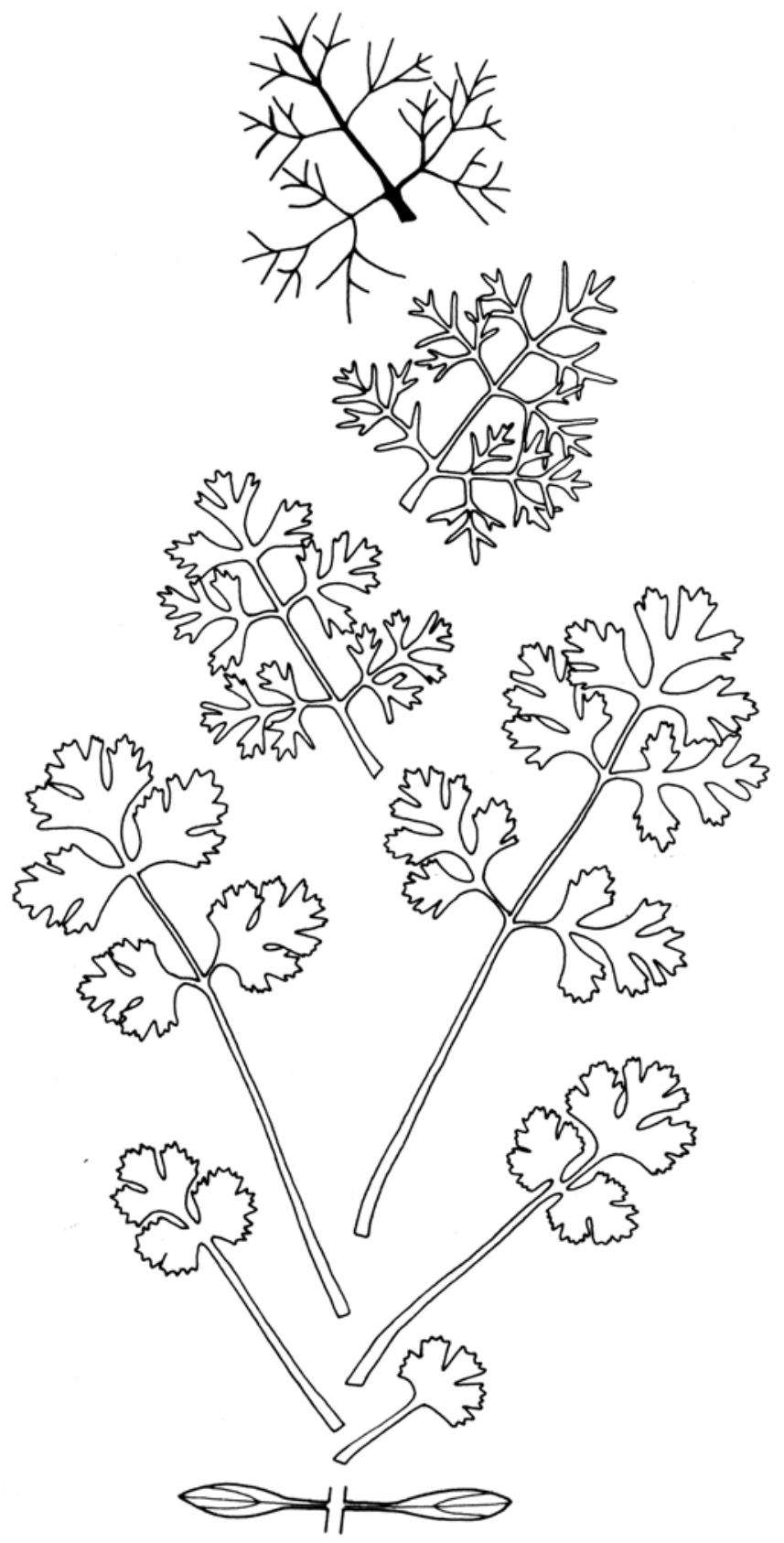

Figura 2 - Representação esquemática dos tipos de folhas de uma planta de coentro. 


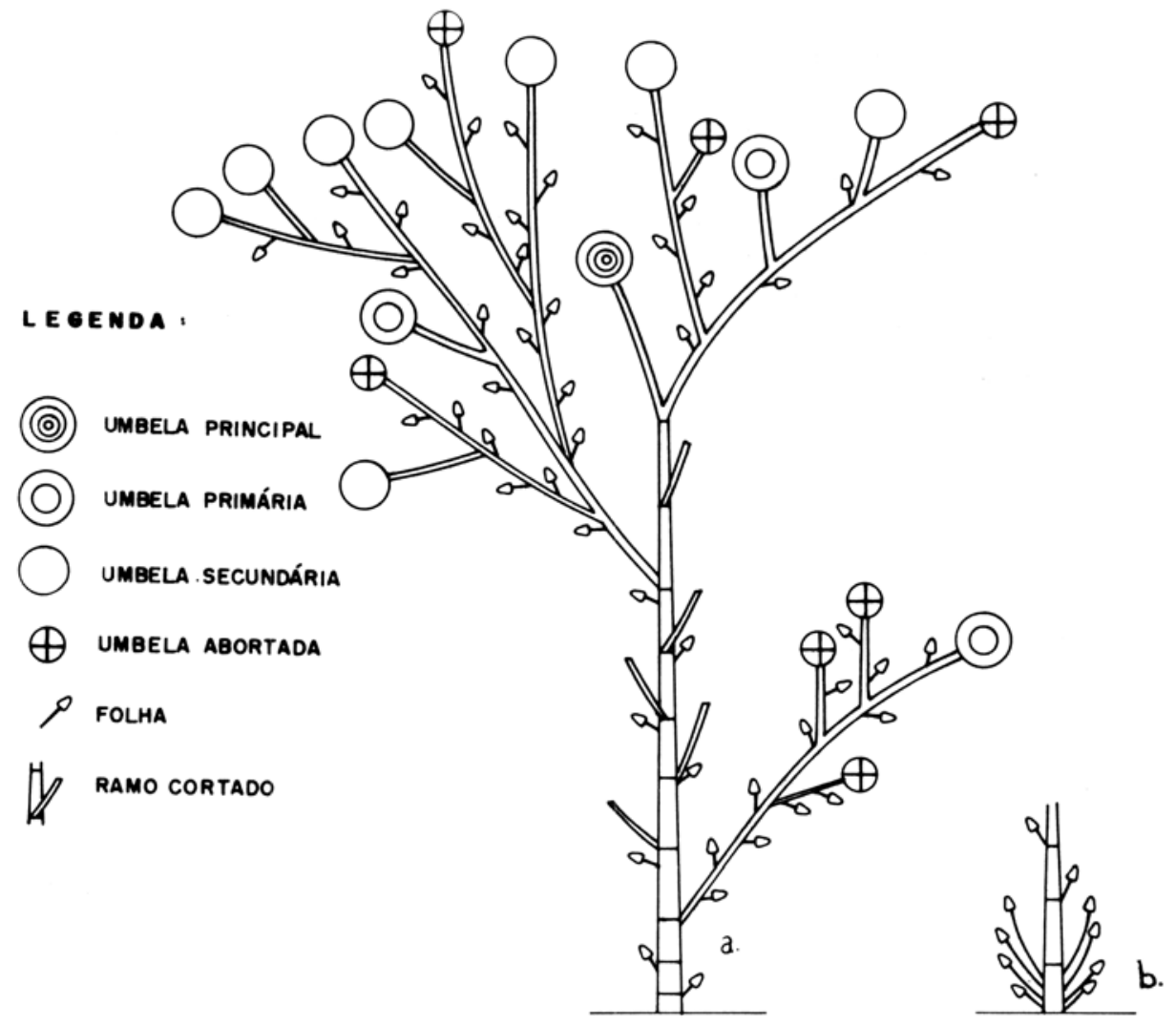

Figura 3 - Esquema de uma planta de coentro na fase reprodutiva mostrando os diversos tipos de ramos e umbelas. a. planta com umbelas em início de amadurecimento; b. planta indicando folhas situadas abaixo do primeiro nó visível.

dias para iniciar o amadurecimento. Por outro lado, as que entram em antese depois do sexagésimo dia após a germinação, umbelas terciárias e quartenárias, portam bem menos de 10 frutos por umbela e requerem, em méida, 10 dias para iniciar o amadurecimento. Estas umbelas, quando surgem, portam bem menos de 10 frutos por inflorescência, apresentando uma alta taxa de infertilidade a ponto de contribuírem com apenas $10 \%$ da quantidade de frutos viáveis da planta.

Em face dos resultados alcançados, pode-se concluir que, para as condições do Estado do Ceará, onde as temperaturas são mais baixas próximo ao meio do ano e altas no início e final do ano, o fator temperatura é o que mais influencia a biofenologia do coentro, alongando o ciclo de vida da cultura, em 20 dias, nos plantios efetuados nos meses mais quentes do ano, neste Estado.

Estudos visando o acompanhamento do surgimento dos diversos tipos de folhas e umbelas devem ser inciados na perspectiva de um melhor manejo para a cultura do coentro tendo em vista a produção de frutos e massa verde. 


\section{Referências Bibliográficas}

BEZERRA, A. M. E.; J. N PINHEIRO; F. C. M CHAVES; J. M. A ALVES; J. C. GASPAR JUNIOR; M. V. ASSUNÇÃO \& J. H. R. SANTOS 1990. Hortaliças cultivadas no cinturão-verde de Fortaleza e análise bacteriológica da água utilizada. Hort. bras. $8(1)$.

SANTOS, J. H. R.; L. C. L. DANTAS \& J. M. A. ALVES 1988. Aspectos biofenológicos da cultura do coentro: fase reprodutiva. Ciên. Agron., Fortaleza, Ceará, 19(2): 1-5. 